\title{
Late lustration programmes in Romania and Poland: supporting or undermining democratic transitions?
}

\author{
Cynthia M. Horne* \\ Department of Political Science, Western Washington University, 516 High Street, \\ Bellingham, WA, 98225, USA
}

(Received May 2008; final version received September 2008)

\begin{abstract}
In 2006, Poland and Romania embarked on renewed lustration programmes. These late lustration policies expanded the scope and transparency measures associated with lustration as a form of transitional justice. While early lustration measures targeted political elites, late lustration policies include public and private sector positions, such as journalists, academics, business leaders, and others in 'positions of public trust'. Given the legal controversy and moral complexity surrounding lustration, why lustrate so late in the post-communist transition and why expand the policies? The dominant explanation is that lustration is a tool of party politics and is a threat to democratic consolidation. However, the late lustration programmes do not fit this hypothesis neatly. The new laws have been restructured and packaged with other reform programmes, specifically anticorruption programmes. Late lustration has evolved to include economic and social, as well as political concerns. As such, some post-communist governments in Central and Eastern Europe appear to be trying to use lustration as a way to further the democratic transitions by addressing remaining public concerns about corruption, distrust, and inequality.
\end{abstract}

Keywords: Poland; Romania; lustration; transitional justice; elites; transition; anticorruption

\section{Introduction}

We had free elections ... we elected a free parliament, we have a free press, we have a democratic government. Yet ... [t] here still exist and work the powerful structures of the former regime ... Many places are governed by the same people as before. They are connected to managers of industrial enterprises. There exist immense bureaucratic colossuses that preclude rational economic behavior of individual enterprises and firms. The old bureaucracy persists in all levels...

Václav Havel, former President of the Czech Republic. ${ }^{1}$

*Email: cynthia.horne@wwu.edu 
Lustration, or the vetting of former communist secret police collaborators from public office, is the Central and East European (CEE) variant of transitional justice adopted in different incarnations by many countries in the region since the fall of communism. Lustration policies, like other vetting policies, 'aim at excluding from public service persons with serious integrity deficits in order to (re-)establish civic trust and (re-) legitimize public institutions'. ${ }^{2}$ This framing of lustration as well as the legitimacy and legality of lustration have been extremely controversial, both regionally and internationally. ${ }^{3}$ Mismanagement of secret police files, salacious accusations about political leaders, illegally publicized personal information contained in the files, questions about the veracity of information, and the proliferation of rumours about wide-scale bureaucratic vetting in many countries in CEE all contributed to fears that lustration was a new form of purging masquerading as transitional justice. ${ }^{4}$

Despite the contentious nature of lustration and many of the early programmatic problems, a wave of countries in CEE has recently opted for late or renewed lustration policies. In 2006, more than 15 years after the 1989 revolutions, both Poland and Romania embarked on new or renewed lustration policies. In 2004, Slovakia reengaged with its previously truncated lustration programme. ${ }^{5}$ In 2004 Slovenia started lustration 12 years after independence, and Latvia renewed its lustration programme 13 years after independence. ${ }^{6}$ In 2007, Macedonia instituted lustration laws 15 years after independence. ${ }^{7}$ Even the Czech Republic has elongated and expanded the scope of its lustration policies since its initial law in 1991, most recently screening police officers and civil employees of police headquarters for former communist secret service ties. ${ }^{8}$ What is driving this wave of late and renewed lustration? Why would countries that are between 12 and 18 years into the transition process decide to embark on morally contentious and logistically complicated lustration policies that could undermine the democratic transitions?

To explore these questions, this paper focuses on the cases of late lustration in Poland and Romania. These countries are interesting comparisons because they are at different stages in their economic and political transitions. Poland has twice the GDP per capita of Romania, and is farther along in its post-communist political consolidation than Romania. ${ }^{9}$ They have different international constraints: Poland became a member of the European Union in 2004, while Romania became a member in January 2007 and continues to be strongly criticized by the EU for lack of progress in meeting anti-corruption and rule of law targets. ${ }^{10}$ They had different approaches to lustration at the start of the transition, with Poland implementing a minimally invasive lustration policy early on, and Romania not adopting any real lustration. Yet, despite the different domestic political institutions, different levels of market reforms, different early approaches to lustration, and the different international constraints, both have chosen similar late lustration policies allegedly to accomplish the goal of democratic consolidation.

I show that in the cases of Poland and Romania, late lustration looks substantially different from early lustration programmes. Late lustration has expanded the 
scope and transparency levels of earlier lustration programmes, rendering late lustration a very different process with a different mandate. The screening and vetting measures no longer focus exclusively on political elites, but include a range of public, quasi-public and even private sector positions. The new measures target a different group of individuals - persons in 'positions of public trust,' broadly defined in social, economic, and political terms. Late lustration policies are reframed and implemented in conjunction with and in some cases as a substitute for anti-corruption measures. Lustration laws are being used by governments to address public frustration and inequity associated with the continued privileging of former communist elites across academe, business, politics and the media. They have been reconfigured with the hope that they can further some of the stalled components of the CEE democratic transitions.

\section{Late lustration policies}

Lustration is a form of vetting specific to CEE, and is narrowly defined as 'special public employment laws [to] regulate the process of examining whether a person holding certain higher public positions worked or collaborated with the repressive apparatus of the communist regime'. ${ }^{11}$ The initial lustration programmes targeted agents of the communist secret services, and temporarily excluded them from key public offices based upon actual involvement or lying about that involvement. ${ }^{12}$ Lustration was rationalized as a form of institutional and symbolic change. Institutionally it would result in bureaucratic turnover, removing individuals from positions of power, and symbolically it would demarcate a break with the past. Both processes are intended work in tandem to restore public trust in institutions. The implementation of lustration has varied across CEE, including truth revelation procedures, publication of information about previous regime involvement, and/or removal from positions of power. ${ }^{13}$

However, this earlier limited definition of lustration, focused exclusively on public office holders or secret police collaborators, no longer captures the evolving nature of the laws. Lustration in practice can now include the screening of politicians, academics, cultural directors, and persons in 'positions of public trust' for previous secret police collaboration or regime involvement in order to determine their suitability for a range of public and quasi-public positions of power. Defining lustration as vetting of politicians no longer captures the reality of vetting in the region. Defining lustration as a process focused on ascertaining secret police collaboration also does not capture the criteria being currently used for employment exclusion. Therefore, early definitions which defined lustration in terms of who was vetted and the criteria on which they were vetted now poorly capture the more expansive and nationally situated process of lustration. ${ }^{14}$ At its essence lustration is a form of employment-vetting: who that involves and the criteria for that exclusion are the subject of debate.

Late lustration has extended the scope and transparency levels of the early lustration programmes in a way which fundamentally changes their implementation 
and intent. First, the scope of positions requiring screening has broadened. Where early lustration programmes focused on political elites and political office holders in top positions of power, late lustration programmes also target lesser positions. Supporting positions in the civil service, and even positions of confidence in the public sector with links to political offices, such as academic positions, journalists, lawyers, school principals, the clergy, and bureaucratic posts are included in late lustration. ${ }^{15}$ Restricting the private sector employment opportunities available to former secret service agents or collaborators expands the scope and scale of retroactive justice beyond ensuring the security of public institutions. ${ }^{16}$ Late lustration is designed to address a larger swathe of society and a different range of institutions, not simply the political elites.

Second, there is more transparency and systemization in late lustration programmes than in the original lustration programmes. More public access to information is built into the programmes, with formalized agencies to safeguard and publicize the names of individuals. Some of the initial lustration programmes have been sullied because of the unofficial publicizing of names of 'collaborators' on the Internet, or the instrumental leaking of information about targeted people. Lustration was designed to be a legal process with due process safeguards and rights to appeal. When the process takes on an extralegal component, or spins outside the control of the agencies designed to safeguard the information and the process itself, lustration starts to look more like the media-hyped 'witch hunts' than a transparent rule of law process. The new laws aim to redress some of the previous problems by increasing transparency and mechanisms of accountability.

For example, Poland's initial lustration programme in 1992 was narrow in scope with limited information access. The tight control over information did not stop the names from being leaked to the press, thereby creating a sense that the lustration process was a 'witch hunt'. ${ }^{17}$ The periodic leaking of names to the press worked to undermine the perception that lustration was done in a manner consistent with rule of law safeguards. Keeping information classified or away from the public can also undermine transparency and credibility. In Hungary, for example, the original lustration law was designed to keep information from the secret files classified for 30 years. ${ }^{18}$ These failed early attempts to minimize transparency delegitimized the lustration laws. By enacting formal disclosure procedures to improve public access and information transparency, the late lustration programmes have consciously designed rules to try to safeguard the implementation and also the legitimacy of the laws.

Why choose renewed and expanded late lustration policies at this point in the transition? There are three possible hypotheses I will explore. First, governments are choosing lustration because they think it will promote good governance and further the democratic transitions. Second, political parties are choosing lustration as a tool against political opposition and challengers. Third, lustration policies are external cues or signals about the political, economic, and social reforms going on within the country and are designed for international audiences such as the European Union. These hypotheses are not necessarily mutually exclusive. 
The following section both specifies and explains the logic supporting each of these hypotheses. The case studies of Poland and Romania will then explore the content and initial implementation of the laws in order to assess the relative merits of the explanations.

\section{Why late lustration?}

\section{Promoting democracy: symbolic and institutional changes}

At its core lustration shares functional and normative features of, as well as moral and legal dilemmas associated with, other post-authoritarian transitional justice measures. ${ }^{19}$ Despite the real moral and legal questions debated with all transitional justice measures, there remains a strong postulated connection between retroactive justice measures and democratic transitions. ${ }^{20} \mathrm{CEE}$ governments have situated themselves within this debate through their lustration policy choices. Many CEE governments claim that they are enacting lustration laws to improve the trustworthiness of public and certain private institutions as part of their larger efforts to promote democratic consolidation. In this framing, lustration positively contributes to the process of democratic consolidation both an act of symbolic politics and a tool of bureaucratic/institutional change.

The Council of Europe affirmed this interpretation in its 1996 resolution On Measures to Dismantle the Heritage of Former Communist Totalitarian System, highlighting how 'old structures and thought patterns have to be dismantled and overcome' through lustration and vetting policies. ${ }^{21}$ The United Nations High Commissioner for Human Rights has highlighted vetting in CEE as an example of constructive transitional justice policies in a post-authoritarian context. ${ }^{22}$ Subsequent lustration cases heard by the European Court of Human Rights have upheld this interpretation about the positive relationship between transitional justice measures, specifically lustration, and democratic consolidation in the CEE context. ${ }^{23}$ As such, despite the controversy surrounding the use and abuse of lustration in CEE, lustration policies remain situated in the larger debate about transitional justice measures in post-authoritarian environments and their relationship to democratic consolidation.

Drawing from the transitional justice literature, CEE governments might be enacting late lustration programmes to effect procedural and symbolic changes that have remained either problematic or neglected in their democratic transitions. Procedurally, late lustration might improve the trustworthiness of public institutions by prompting more extensive bureaucratic turnover and institutional change. In CEE, there is a strong correlation between current positions of economic and political power and previous positions in the communist regimes. ${ }^{24}$ Many CEE countries have seen former communist elites continue to cycle into new positions of power, with lustration failing to effect the projected institutional changes. By 2002, 63\% of current leaders in Romania were also political leaders before $1989 .{ }^{25}$ O'Dwyer's work has examined how large-scale public 
administrative personnel additions can result in little reform and even counterproductive consequences, despite direct efforts to improve public institutions. ${ }^{26}$ As Havel's quote from the beginning suggests, despite free elections 'the old bureaucracy persists in all levels'. ${ }^{27}$

Economically, informal networks of former secret police officials continue to dominate economic activities. In Romania, it has been demonstrated that the most significant factor predicting membership in the new business elite was past membership in the communist elite. ${ }^{28}$ In Poland the "major corruption scandals mixing business and politics have generally involved individuals connected with the communist era secret police' ${ }^{29}$ Corruption levels have risen in Poland as economic growth has advanced, and popular dissatisfaction with public institutions has grown with increases in economic inequality. ${ }^{30}$ Polish and Romanian academics have emphasized how informal understandings and unwritten agreements between current political elites and former elites in positions of economic power have created widespread perceptions that the transitions were unfair and incomplete. ${ }^{31}$ Governments in the region are being pressed externally and internally to address corruption and inequality of opportunity issues.

Symbolically, the countries in CEE could also be using lustration policies to signal a break with the past. A symbolic break might be especially important in the case of negotiated settlements, or relatively peaceful regime transitions, in which a power-sharing agreement between opposition groups and the regime in power was negotiated. ${ }^{32}$ The peaceful CEE 'Velvet Revolutions' are examples of negotiated settlements. However, there is growing debate in CEE about whether the price of peace in negotiated settlements was too high. For example, in the Polish case a 'thick line' was drawn between the past and the present, with no clear bureaucratic reorganization to demarcate the change. ${ }^{33}$ Questions are arising about whether the concessions made at the Polish Round Table talks might have overly minimized retroactive justice concerns: 'Many on the right now regard the talks [Round Table] as a corrupt trade-off of power for impunity. ${ }^{34}$ Therefore, an optimal strategy for peace in the short term might have ignored retroactive justice concerns, perpetuating a sense of continued injustice in the new system.

According to this argument, governments choose expansive lustration late in the transition in order to effect political, economic, and social reforms that have remained problematic. What would the late lustration programmes look like to support this hypothesis? The programmes would be broader in scope than early lustration programmes. They would target a wider swathe of institutions and positions than simply national-level political elites. If the problems the government was trying to tackle were economic, social, and political in nature, the new laws would consider the competency and integrity of individuals in positions of power, broadly defined in economic, cultural, social, and political terms. Additionally, if lustration was designed to promote unrealized reforms in public institutions, the original focus on public positions would be expanded to include supporting institutions as well, such as quasi-public and in some cases private positions. 
Symbolic changes might require a change in the narrative surrounding late lustration, with a focus on morality and renewal that had been less developed in the past. Symbolically, one might predict that lustration laws to cue off of politically and socially salient issues, directly addressing issues related to morality, equity, and injustice. In essence, the expanded laws would aim at both broad bureaucratic and administrative change, as well as tap into an important cognitive or symbolic component to citizens' perceptions of governance and public institutions.

Finally, if late lustration was designed to effect yet unrealized institutional reforms, the new programmes would specifically correct problems with previous lustration programmes. Those problems could be legal or moral. If legitimacy and credibility were problems with previous lustration programmes, the new lustration laws would directly address these problems by changing accountability mechanisms, improving transparency, and designing new oversight agencies in order to guarantee the fair implementation of the laws. As such, this series of hypotheses would suggest fundamental changes in the structure, intent, framing, and implementation of the late lustration laws, reflected in changes in scope and accountability.

\section{Alternative hypotheses: political manipulation and international signalling}

Despite the intentions of the regional governments, 'the dominant view in the academic literature is that transitional justice is counterproductive because it interferes with the development of democratic institutions and market economies'. ${ }^{35}$ Offe provides an arsenal of highly thought-provoking reasons why vetting, lustration, and other forms of transitional justice could undermine trust in public institutions and the goals of good governance. ${ }^{36}$ The dominant explanation for late lustration fits within this alternative framing of lustration, highlighting how late lustration in particular is a function of party politics.

A narrowly defined party politics explanation would contend that lustration laws are politically manipulated by political parties in order to gain political advantage. This advantage could take the form of disadvantaging current or former political opposition, undermining the strength of certain candidates, personally advantaging one's own party, or bringing in a new younger cadre of politicians not associated with the communist past. ${ }^{37}$ From this perspective, the laws are often described as 'weapon[s] for exacting revenge against opponents' or as means to 'demobilize lawful opposition to the present regime, or, quite simply, as a method to exact personal revenge, ${ }^{38}$ If lustration policies are elite-driven acts of electoral politics, these laws could undermine the process of democratic consolidation. If government motivations for lustration are duplicitous or selfserving, citizen perceptions of government won't change and government competencies won't change. Even worse, having political parties or politicians engage in blatant acts of political posturing for personal gain could undermine citizen trust in the very fledgling public institutions that represent them. Therefore, if this 
hypothesis holds true, it would suggest that late lustration might fail to promote or at worst could actively undermine the trustworthiness of public institutions and the process of democratic consolidation.

Testing this hypothesis is trickier than it appears. Lustration policies, like other transitional justice measures, are politically motivated. They are generally enacted by recently elected political parties or new political regimes, who then use their newfound voice to implement political changes. ${ }^{39}$ Whether politically motivated laws become politically manipulated laws - laws used by a political party for personal advantage rather than to further democratization - is at the heart of the lustration controversy. The test of political manipulation is if the laws are wielded against political parties for personal gain, not whether or not they result from political turnover or whether there are political implications.

If a political manipulation hypothesis were to hold true, one would see the personal advantaging of the party in power who enacted the expanded or renewed lustration policies. If these policies resulted from party politics, one would expect to see these policies being largely elite-driven, benefiting political and economic elites. This would be especially true for renewed or expanded lustration, which would simply perpetuate cycles of political manipulation of the laws and consume time and resources without actually advancing a reform agenda.

This definition of party politics is intentionally narrow, in order to avoid the danger of an unfalsifiable and unverifiable party politics hypothesis. Lustration laws are political, and their impact will be political. Teasing out when the lustration laws are expanded in order to gain direct personal political advantage, from when the laws are expanded in order to effect political changes with possible indirect political implications, is admittedly complex. However, by focusing on direct rather than indirect political advantage and differentiating politically motivated laws from politically manipulated laws, one can explore whether a party politics hypothesis captures the dynamic of late lustration. Given that the motivation for the laws as well as the implementation of the laws is important to the process of creating trustworthy public institutions, this difference is critical.

A second alternative explanation is that lustration could be an external signal to foreign investors, international institutions and actors, and other EU member states that domestic reform programmes are continuing to move forward. The problem with focusing on external actors is that this could mean the policies don't resonate with domestic-level concerns. The legitimacy of the policies rests on the extent to which they are considered socially, politically, and economically authentic by CEE citizens. For example, in the case of Romania, perhaps lustration was an attempt to cue international actors, such as the European Union, that it was tackling economic and political reform issues, specifically its corruption problems, prior to joining in January 2007. Poland's flagging economic growth rates and rounds of political corruption charges pushed Poland down from its position as a vanguard of the Visegrád to an economic laggard. ${ }^{40}$ Perhaps late lustration was an attempt to revitalize international investor interest in the Polish economy. 
If the laws were designed for external rather than domestic actors one would expect them to be strongly supported by international actors and domestic affiliates of international bodies. One might expect to see some international reward from the laws, either directly tied to the lustration reforms or as an acknowledgment of the continued reform efforts. Signalling international actors about reforms could go hand in hand with changing citizen perceptions of the trustworthiness of their own public institutions. Therefore this explanation could complement the first explanation, but not the second.

The following sections will take up the cases of Poland and Romania in order to assess the relative strength of the explanations. The cases will try to address the question why late lustration? What late lustration might mean for democratic consolidation is taken up in the conclusion.

\section{Poland}

\section{Background}

From the very beginning Poland has had a complicated relationship with its lustration laws. Various rounds of failed draft legal proposals, several leaked lists of collaborators, and cyclical repudiation of lustration and then adoption of laws, sometimes timed with the rise and fall of political parties, have all created a morally discordant and logistically haphazard approach to lustration. In 1989 the first parliamentary motion on lustration was passed, and in 1992 the first lustration attempt was made. However, it wasn't until 1996 that the Sejm (lower house of parliament) began work on a comprehensive draft law, and in August 1997 a screening law finally entered into force. ${ }^{41}$ The lustration programme concentrated on screening rather than vetting people for collaboration with the Stużba Bezpieczeństwa (SB) or the secret police services, so people were not removed from positions unless they were shown to have lied on their lustration certificates.

The law created a Lustration Court to verify the declarations of top officers, and to punish in the event of false statements. Some public officials resigned over collaboration allegations, but largely there was limited bureaucratic turnover. ${ }^{42}$ The implementation of the 1997 lustration laws has been criticized as incomplete, non-systematic, and highly arbitrary, exacerbated by the lack of will on the part of the Courts to implement the law. ${ }^{43}$ It was not even possible to recruit the 21 judges required to sit on the Lustration Court, thereby effectively stalling the implementation of the laws for some time.

The Institute of National Remembrance (IPN) was created in 1998 and charged with archive custodial functions, as well as responsibilities to assist with the review of collaboration claims and background reviews of public office seekers. ${ }^{44}$ However, there were still substantial problems with management of information and implementation of the laws. Specifically, in 2005 a journalist stole an IPN unofficial list of up to 240,000 'collaborators', nicknamed 'Wildstein's List', and posted the information on the Internet. The list was not credible, proved 
highly inflammatory, and was timed to coincide with the 2005 round of elections. ${ }^{45}$ At this point, the original truth telling nature of the programme had become sullied by electoral politics. When Lech Kaczyński decided to make 'building a new moral order' Law and Justice Party's platform in 2005, the unpredictable and at times arbitrary nature of the previous lustration programmes had undermined the credibility of the laws.

\section{Late lustration in Poland}

By 2006 Polish lustration had been described as 'no lustration at all'. ${ }^{46}$ Lech and Jarosław Kaczyński of the Law and Justice Party partially blamed the widespread corruption and cronyism on the former spy network and its continued influence on Polish society, faulting the lack of a true retroactive justice element to the transition. ${ }^{47}$ At Lech's inauguration he reiterated his moral cleansing mission: 'Poland absolutely needs to establish moral order, and this moral order means also our efforts to deal with the burden of the past by rejecting it ... This can be achieved by political screening. Vetting must be carried out with all determination. ${ }^{48}$ Thus, the goal of building a new moral order was directly tied to a new lustration programme. In November 2006 a new lustration plan was ratified, and it went into effect on 15 March 2007. The new programme substantially expanded the scope and transparency of previous lustration efforts.

The scope of the vetting programme changed in two ways. First, the types of positions for which vetting would be required expanded. The previous screening laws applied to ministers, members of parliament, and senators, essentially traditionally defined public office holders. The new laws would require the screening of 53 categories of workers or persons in 'positions of public trust', including teachers, academics, journalists, state company executives, school principals, diplomats, lawyers, police, and other broadly defined civil servants. ${ }^{49}$ This was consistent with early drafts of the 1997 law, which had never come to fruition. ${ }^{50}$ One of the areas of 'public trust' controversially omitted was the clergy. ${ }^{51}$ Second, the definition of collaboration also changed, loosening the conditions under which 'collaboration' could be found. ${ }^{52}$ This definitional change would classify people as collaborators who had contact with or were harassed by the secret police. This was a politically charged decision because it overturned a 2000 Supreme Court ruling that decided this level of involvement did not constitute collaboration.

With the expansion in scope, a greater number of persons would be screened. The previous lustration law required screening of approximating 27,000 senior office holders. By contrast, the new vetting law would require all Poles born before 1 August 1972 and in positions of 'public trust' to complete a vetting certificate. Depending on the final implementation of the law, this could include anywhere from 300,000 to 1.5 million people, with the figure 700,000 routinely cited. $^{53}$ It is estimated that implementation of the laws, as currently drafted, could take ten years. ${ }^{54}$ As before, individuals who lied about their regime 
involvement would be banned from certain public employment positions for ten years. However, the longer time period for implementing the laws suggested a commitment to a longer lustration process than before.

The new laws increased the transparency of the lustration programme. The original lustration laws shielded information from publication for 30 years, with information being declassified on 1 January each year. ${ }^{55}$ Under the new law, the security service files would be published on the Internet. Employers would also be required to verify that they had vetted their employees. This expanded the locus of responsibility from the individual alone to the individual and the employer. ${ }^{56}$ It increased the public nature of the laws and provided a built-in enforcement mechanism.

In May 2007, before the 15 May deadline to file lustration declarations, the Constitutional Court struck down elements of the expanded scope of the new law. It argued that both the categories of individuals and the definition of collaboration were too expansive, and the lack of a right to appeal to the Supreme Court was unconstitutional. ${ }^{57}$ Specifically, it argued against the retroactive nature of the lustration law, a verdict that resonates with the main debates in transitional justice. Therefore the expansive scope of the new lustration programme, which was the crux of the lustration reform, was ruled unconstitutional in many respects. The Court asked the current government to review the laws in order to make changes that would bring them into compliance with the Polish Constitution. Despite the Civic Platform victory in November 2007, in which Jarosław Kaczyński was replaced as prime minister by Donald Tusk, the president has said he would continue with his previous mandate and is drafting another lustration law. ${ }^{58}$ How this issue will be resolved is presently uncertain. However, the original question remains, why late lustrate so late in the transition?

\section{Why lustrate?}

This paper has suggested three possible reasons why a government would choose expanded lustration: 1) to try to create confidence in the trustworthiness of public institutions in order to promote democratic consolidation; 2) as a way to disadvantage political competition; and/or 3) as an international signal about reform efforts. Which does the legal structure of the laws and popular perception about the laws suggest is the dominant explanation?

First, if the new laws were designed to promote institutional trustworthiness, they would target the political, economic, and social institutions of public trust, rather than focus myopically on the political elite. Institutionally speaking, the new laws were broadly aimed at 'positions of public trust'. They were not targeting the political office holders as they have in the past. Laws targeting journalists or academics or school principals are not tools to offset the power of rival political parties. The new laws were targeted at a much larger swathe of society, suggesting they were addressing bigger issues of justice, economic and political equality, and social privileging. Targeting positions that are not directly linked to public office 
holders does not support a hypothesis that a party in power was using the laws to disadvantage political competition.

Second, if the new laws were trying to enhance the trustworthiness of public institutions, they would correct past problems with transparency. With limits on publicly available information or incremental revelations about files, the process has been criticized as arbitrary and non-transparent. This has fuelled fears of political manipulation. To combat this, the new laws would open all of the files and publish them on the Internet. This would prevent political blackmailing or secret information revelations. Kaminiski and Nalepa point out that the key factor distinguishing lustration from decommunization is the vulnerability to blackmail. ${ }^{59}$ Removing selective access to information reduces this danger. As a show of transparency, the Kaczyńskis were some of the first to have their files publicized.

The Polish system does not disqualify people from positions because of past involvement; people who lie about that involvement are removed from office. Therefore, built into the structure is a control mechanism against overt political manipulation, but it is based on full transparency. Opponents of previous lustration have changed their minds, and endorsed the calls for increased transparency in the latest lustration programme. Michnik has called for the files to be opened, as a way to increase the transparency of the information. ${ }^{60}$ Walesa took it upon himself to publish the files, accepting that full transparency of the information was the best way to move past this problem. As Walesa said, 'I got sick and tired of the constant accusations, doubts and insinuations being peddled by these people and decided to publish these materials for all to see'. ${ }^{61}$ When calls for transparency are endorsed by previous opponents of lustration, and transparency of information is demonstrated by the party implementing the changes, this suggests motives other than political manipulation of the files for direct personal gain.

Third, if the lustration programmes were designed to increase institutional trustworthiness and promote democratic consolidation, they would address popular concerns about economic and political equity. The late lustration laws have become explicitly linked to anti-corruption programmes by the implementing governments. Late lustration proposals have been debated concurrent with and sometimes in conjunction with anti-corruption measures in parliament. Corruption has continued to be an enduring problem for all of the post-communist countries. Not only have corruption levels increased in CEE, but there is a marked increase in the salience of corruption as a political issue in the region. ${ }^{62}$ As Table 1 shows, measures of corruption and perceptions of corruption have gone up over time in Poland.

By linking lustration with anti-corruption measures, the expanded justice programme is aimed at redressing continued economic and political nomenklatura networks. The economic inequalities and continued aggrandizing tendencies of the Polish elites were two important motivations cited by the current Polish government in the enactment of the 2007 lustration law. ${ }^{63}$ The continued perception that some people remain above the law have contributed to low levels of citizen 
Table 1. Trust and Corruption.

\begin{tabular}{|c|c|c|c|c|c|c|}
\hline & 2001 & 2002 & 2003 & 2004 & 2005 & 2006 \\
\hline \multicolumn{7}{|c|}{ Poland: Trust in Various Public Institutions } \\
\hline Civil Service & 28 & 34 & 24 & & & \\
\hline National Government & 30 & 27 & 14 & 7 & & \\
\hline Judiciary & 29 & 34 & 24 & 21 & & \\
\hline Police & 43 & 47 & 42 & 43 & & \\
\hline Trade Unions & 20 & 20 & 25 & 21 & & \\
\hline Public Institutions & 25 & 24 & 15 & & & \\
\hline \multicolumn{7}{|c|}{ Poland: Corruption Measures } \\
\hline \multicolumn{7}{|c|}{ Freedom House Corruption Levels (1-7, lower number less corruption) } \\
\hline & 2.25 & 2.25 & 2.5 & 2.5 & 3 & 3.25 \\
\hline \multicolumn{7}{|c|}{ CPI (0 high corruption-10 low corruption) } \\
\hline & 4.1 & 4 & 3.6 & 3.5 & 3.4 & 3.7 \\
\hline \multicolumn{7}{|c|}{ Romania: Trust in Various Public Institutions } \\
\hline Civil Service & 32 & 33 & 34 & & & \\
\hline National Government & 41 & 37 & 38 & 36 & & \\
\hline Judiciary & 29 & 30 & 35 & 29 & & \\
\hline Police & 35 & 38 & 43 & 40 & & \\
\hline Trade Unions & 22 & 22 & 27 & 26 & & \\
\hline Public Institutions & 29 & 30 & 30 & & & \\
\hline \multicolumn{7}{|c|}{ Romania: Corruption Measures } \\
\hline \multicolumn{7}{|c|}{ Freedom House Corruption Levels } \\
\hline & 4.5 & 4.75 & 4.5 & 4.5 & 4.25 & 4.25 \\
\hline \multicolumn{7}{|c|}{ CPI (0 high corruption-10 low corruption) } \\
\hline & 2.8 & 2.6 & 2.8 & 2.9 & 3 & 3.1 \\
\hline
\end{tabular}

Sources: Inter-University Consortium for Political and Social Research.

Candidate Countries Eurobarometer. Various years. Www.iicpsr.umich.edu Freedom House, Nations in Transit: Democratization from Central Europe to Eurasia. (2007). http://www.freedomhouse.hu/ index.php?option $=$ com content\&task $=$ view\&id $=84$ Transparency International, various years. Corruption Perceptions Index http://www.transparency.org/policy_research/surveys_indices/cpi/ 2001.

trust of the new public institutions. ${ }^{64}$ For example, the richest Polish businessmen today had extensive contacts with the security services prior to 1989 , a charge repeated by former Interior Minister Antoni Macierewicz. ${ }^{65}$ Those Polish secret police agents who did not make it through the vetting process successfully ended up in private security companies, business and the Mafia. ${ }^{66}$ This allowed former secret service networks to persist and flourish in the private sector - one of the reasons why the expanded lustration law has also targeted related private sector positions. There remain public questions regarding how the fortunes of the rich were accumulated. This feeds a perception that prior regime collaboration has not only gone unpunished, but continues to economically and politically privilege a group of elites.

There was also a push for increased transparency and information about the Military Intelligence Service (WSI), a highly secretive agency that penetrated all aspects of political, economic, and social life including the media, universities, 
and social organizations. The new law required the screening of its agents as well as the disbanding of the agency itself. ${ }^{67}$ The former Prime Minister Kazimierz Marcinkiewicz directly linked the major political scandals in Poland with the unreformed and unvetted intelligence service. ${ }^{68}$ As one government official commented, 'This is the biggest bugbear: a lawless, unreformed communist era bureaucracy, that has escaped all political control. ${ }^{, 69}$ Given the nature of this organization and its continued links to business and political networks, its ability to avoid lustration for the past 18 years is rather remarkable and an indication of the flawed nature of previous programmes. It is also an indication of the desire of the new programme to tackle unresolved problems with the transition, even if they are politically sensitive. If the most influential business and political networks are going to be targeted, this cannot be politically advantageous in the short term to the party that implements these changes.

There is also interest in having the new lustration laws target past privatizations. Special investigations of certain privatizations have been raised, including a suggestion to allow the state to take over a company that was built 'unjustly or with communist connections' ${ }^{70}$ Investigating lingering economic injustices that might have gone unpunished thus far is consistent with a hypothesis that the laws are designed to redress problems in the transition and promote democratic reforms in post-communist societies.

Fourth, public opinion about lustration affects its relative utility. If lustration is intended to have a symbolic impact and therefore affect citizen perceptions of public institutions, it must resonate with the population as legitimate. In 1991, $38 \%$ of Poles supported lustration. In 1992 64\% supported lustration policies, jumping over the one year period in which there were cycles of presidential intrigue. $^{71}$ In 1994, public opinion polls showed $75 \%$ of respondents thought SB collaborators should not occupy senior state posts. ${ }^{72}$ From $1994-1999$ a clear majority of Poles favoured vetting key political officials for links with the SB, with only one in three opposed to lustration. ${ }^{73}$ Even after several failed rounds of lustration in $2000,52 \%$ of Poles thought lustration of presidential candidates was necessary, with $72 \%$ saying they thought it was important to know about the past of candidates, and $10 \%$ thinking that lustration policies in particular did in fact prove the trustworthiness of candidates. ${ }^{74}$ More recent public opinion polls (2006) have shown that Poles favour the principle of vetting as 'an essential cleansing process' that was not carried out immediately after communism. ${ }^{75}$ While these attitudinal indicators are not definitive, they suggest that late lustration is tapping into concerns that appear legitimate to the national population.

There is a collective sense that the past actively affects the political and economic reality of the present. A historian working at IPN explained, 'We cannot move forward ... [until] we make sure that the people who shape our future are not implicated in the past. ${ }^{76}$ Universities preempted the enactment of the law, and starting probing their own staff with an eye toward 'the scores of academics [who] were zealous SB collaborators in the $1980 \mathrm{~s}^{\prime} \cdot{ }^{77}$ If the late lustration policies were simply tools of political manipulation designed to advantage the political 
elite, they would actively opposed by the very agency that is the repository of files on the past. Universities would also protest the use of the files, which in many cases were going to require self-lustration and could negatively impact the university staff. Neither of these agents directly supports or advantages the party in power, which again fails to support an argument that the laws are politically manipulated to achieve party advantage.

Fifth, the media has broadly framed the new lustration laws as an attempt by the Kaczyńskis to purge an entire generation of older politicians from public office, and more narrowly as a tool of revenge wielded by the brothers against Solidarity in general and Lech Walesa specifically. ${ }^{78}$ This characterization fits with a hypothesis that the laws are manipulated for personal political advantage by the party in power. However, arguments that the laws are party politics dressed up as transitional justice don't capture the nature of political cleavages or party politics in Poland well. While Poland has had substantial political turnover, there have not been clear anti-communist forces lobbying for lustration and pro-communist force arguing against it. Poland's lustration issues have not cleaved along what would be traditionally hypothesized party lines. ${ }^{79}$ This time around, several prominent dissidents, including Walesa himself, have changed their minds and supported a more open lustration process for once and for all. Despite the political cycling that has gone on with lustration in Poland, there have been no clear winners. All parties have been harmed by the inability to implement transparent and fair transitional justice programmes.

One of the alternative hypotheses suggested that late lustration policies might be designed for external audiences, signalling positive changes in the domestic environment. However, there are potential negative economic consequences to this retroactive justice measure. The new laws called for the lustration of state company executives and business leaders. The Financial Supervision Authority (KNF), Poland's new unified banking corporate and financial markets regulating organization, feared that if board members and managers of companies were lustrated this could provoke financial uncertainty and possibly an economic downturn. ${ }^{80}$

Moreover, the Council of Europe has explicitly questioned the legality of the expanded law and suggested that certain elements could undermine sound rule of law practices. ${ }^{81}$ The Council of Europe's Commissioner for Human Rights explicitly criticized the new law saying 'it does not uphold the standards of a state based on rule of law and respect for human rights' ${ }^{82}$ In addition, the Helsinki Committee of Poland, a national affiliate of a broader international NGO community committed to upholding the International Helsinki Federation of Human Rights, formally questioned the legality of the expanded laws. ${ }^{83}$ Given the negative political and economic reactions by the international community to the expanded lustration programmes, this does not support a hypothesis that the laws are designed as international signals about reforms.

In sum, the expansive scope of the new lustration law suggested a concerted effort to change the bureaucratic composition and competencies of institutions 
across political, economic, and social spheres. The laws appeared authentic to the population, and targeted social inequity, corruption, and economic inequality of opportunity that were of concern to the population. Both the transparency and accountability measures included in the new programme were substantial legal changes that would correct some problems with the implementation of previous lustration programmes. While no one piece of evidence about the laws is sufficient to prove that the leadership designed expansive late lustration policies to promote democratic consolidation, these three components together all affirm the same hypothesis. Late lustration laws look like reformist tools, designed and framed by the government as a way to create an institutional and symbolic break with the past in order to further the democratic transition. Whether a lustration programme will or could accomplish such a feat remains to be seen.

\section{Romania}

Romania presents an interesting contrast to Poland. Despite its having one of the most pervasive and active secret police presences in CEE, lustration has been almost non-existent in Romania. In terms of the nature of the transition, the bloody removal of Ceausescu was a far cry from the Round Table talks in Poland. Romania was not part of the Visegrád Group of early reformers, receiving the dubious distinction of "the most corrupt among countries seeking accession to the [European] Union ${ }^{84}$ (see Table 1). In essence, Romania was in a different political, economic, and international situation from Poland, but opted for a similar late lustration programme. 'Why lustrate so late in the transition' is an equally compelling question for Romania.

\section{Background}

In March 1990, just months after the November 1989 revolution, the Proclamation of Timişoara called for lustration of the Communist Party nomeklatura and Securitate cadres ${ }^{85}$ Despite this early popular movement for transitional justice, Romania's first post-1989 president pardoned members of the Ceausescu family and high-ranking Communist Party members, thereby foreclosing that possibility. ${ }^{86}$ By 1996, Romania had made the least progress of countries in the region in the screening of security personnel or pursuing transitional justice. ${ }^{87}$

The first centre-right government came to power from 1996-2000, and initiated a series of transitional justice measures. In October 1999, the Ticu Dumitrescu Law was passed, creating the Council for the Study of the Securitate Archives (CNSAS) to oversee the secret police files, control public access to this information, and oversee compliance with the lustration measures. ${ }^{88}$ The Constitutional Court rejected a challenge to the constitutionality of the law in November 1999. ${ }^{89}$ The CNSAS was formed, but the substantial delays appointing council members, funding the body, giving it a place to function, or even providing it with the files, essentially rendered it symbolically important but institutionally ineffectual. ${ }^{90}$ 
In 2004 the Justice and Truth political coalition pushed forward with a renewed lustration programme, supported by President Traian Basescu. In 2005, there were two parallel lustration initiatives in Parliament designed to build on this work: one more radical proposal from the National Initiative Party and the other a relatively more moderate, although still substantially expanded, proposal put forward by the National Liberals. The National Liberals' proposal was passed by the Senate in April 2006. ${ }^{91}$ However, the Chamber of Deputies, which has the final say, 'has shelved the document indefinitely'. 92 In December 2006, President Basescu formally condemned the communist regime and in mid-May 2007 he once again affirmed his commitment to a comprehensive lustration programme. ${ }^{93}$ At this point, it remains unclear what the status of lustration will look like.

Despite the legal morass, the CNSAS has continued to review files and issue rulings. Because the lustration law has not been finalized, the CNSAS's verdicts are largely symbolic, although they are believed to have moral value. ${ }^{94}$ The work of the CNSAS and the lustration laws were challenged by the Constitutional Court in January 2008, which ruled that certain aspects of the CNSAS's work assumed juridical attributes that infringed on rights and liberties and were therefore unconstitutional. ${ }^{95}$ The government adopted an emergency decree to overrule the Court and allow access to the files, thereby allowing the CNSAS to continue its work. ${ }^{96}$ As with the Polish case, the future of the expanded lustration programme is not yet known.

\section{Late lustration in Romania}

Despite the murky future of the lustration programme in Romania, why late lustration is an important question. As in the Polish case, the Romanian laws expanded the scope and transparency of the laws. The scope of the laws increased in two ways. First, the list of positions requiring lustration widened, affecting politicians at national, regional, and local levels. While major political offices remain on the list, such as the president, parliament, and directors of government institutions, local regional positions would also be subject to lustration, including mayors, judges, inspectors, and local officials. Major security positions in the police and army at all levels were also included. In addition to traditionally understood political positions, the media, the clergy, and academics would also be subject to lustration. Moreover, managers of central or local cultural institutions would require lustration, as would other cultural figures and persons in 'positions of public trust'. 97 The expansion of lustration to quasi-private sector positions as well as cultural positions suggested that the new laws were broadly aimed at positions in civil society.

The definition of collaboration also expanded the scope of the proceedings. Collaboration sufficient to preclude employment possibilities includes active participation in the Romanian Communist Party and the Union of Communist Youth at national, regional or county levels. Work with the Council of Socialist Culture 
and Education in any propaganda capacity, for example, editors or secretaries in press institutions, would be prohibitive. Professors in party schools would be excluded, as would individuals who held ranking positions in banks or who worked in foreign currency operations. Finally, former Securitate officers, members of the militia and former judges would also be affected by the lustration law. In this way, both the scope of positions and the scope of collaboration expanded. Notably, collaboration does not hinge on secret police collaboration, thereby suggesting that the traditional definition of lustration no longer fits with the expansive nature of the proposed vetting programme.

The expanded scope has increased the consequent size of the vetting net. 1.35 million files have been transferred to the Council for review and declassifying. ${ }^{98}$ Given the estimated eight miles of files, it could take ten years for the files to be revealed. ${ }^{99}$ This would extend the process of lustration substantially into the future and refocus the laws away from a purely truth-revelation exercise.

In addition to the substantial changes in the scope of the laws, the government designed the new law to improve the transparency of the proceedings by removing the classified status from the archives of the Central Committee of the Romanian Communist Party and releasing the Securitate files to CNSAS. ${ }^{100}$ This opened access to information, and freed files that had previously been classified for 40 years. Under the previous lustration programmes, only those files classified as 'political police' meaning people who collaborated with the Securitate could be lustrated. Part of the new lustration law involves potentially reclassifying all files as 'political police', qualitatively expanding the scope of information available, and therefore the depth and transparency of the lustration procedures. ${ }^{101}$

Moreover, there are a number of actors now involved in the lustration process. The process is not centralized or controlled by a single locus of power. A multiplication of institutions became involved with the truth revelation/investigation process, including, two truth commissions, a presidential commission, and a government institute, as well as smaller fact-checking commissions which independently developed to verify the work of the national investigation commissions. ${ }^{102}$ These multiple levels of accountability also suggest something fundamentally different about the transparency of the new lustration efforts.

\section{Why lustrate?}

The question 'why lustrate?' is equally compelling in the Romanian case. Does the Romanian case confirm a political competition hypothesis better than the Polish case? What national or international conditions might explain late lustration in Romania?

First, the scope of the new lustration programme in Romania was similar to the Polish case. The types of positions targeted went well beyond political elites, broadly addressing so called 'positions of trust'. The government defined these positions of trust to include local and regional political and economic officials, and persons in positions of cultural or moral authority, such as academics and 
journalists. In terms of institutional impact, it was designed for a maximal effect on public and quasi-public institutions at all levels. The laws appear to target the perceived problem of low levels of bureaucratic change. The laws do not ignore top-ranking political office holders, but they are not focused on this group exclusively. The wide purview of the laws suggests a larger reformist strategy aimed at both public institutions and the civil society institutions that support them. Moreover, the lustration programme explicitly addresses moral values and public trust, thereby tapping into the hypothesized symbolic intention of the laws in furthering the process of democratic consolidation.

The targeting of the clergy for lustration in the Romanian case is an example of the symbolic nature of the programme. The clergy has admitted to widespread collaboration with the Securitate, and has been included in the list of positions of trust to be lustrated. ${ }^{103}$ The clergy is not directly affiliated or supported by a political bloc, therefore lustrating this category of individuals cannot be explained as a function of gaining direct political advantage on the part of the implementing party. Moreover, lustrating the clergy could negatively impact the party in power, since the church enjoys the highest levels of public trust of Romania's public institutions (83\%). ${ }^{104}$ The targeting of the clergy fits with the moral cleansing narrative being put forth to partially explain lustration. If lustration is hypothesized to catalyze both institutional and symbolic change, it would include these types of positions with moral resonance.

Second, if the new lustration law was designed to support the democratic transition, it would increase transparency and accountability in order to reduce the potential for the laws to be politically manipulated. The declassification of all categories of files and the strengthening of the power of the CNSAS suggest an attempt to correct information management problems. ${ }^{105}$ As mentioned, there are many agents involved with the implementation of this programme, suggesting once again a lack of party orchestration of the process for direct political gain. In conjunction with the multiple sources monitoring lustration, there is a push by the government for more media openness with respect to politics as a whole and lustration in particular. ${ }^{106}$ This also supports an argument that the government is trying to increase transparency in order to improve the legality and legitimacy of the process.

Third, Romania's lustration efforts were bundled with other reform programmes, including constitutional reforms, reformation of the political class, changes in voting structure to be more inclusive of minorities, and national security changes, suggesting a larger reformation mandate. ${ }^{107}$ The lustration law was proposed and circulated in Parliament at the same time as an anti-corruption law. The anti-corruption proposal got caught in political fighting and expired before it could be acted upon. ${ }^{108}$ Additionally, the lustration laws were adopted in conjunction with a draft law reforming the intelligence service. ${ }^{109}$ After 1989, approximately 1600 former Securitate officers ended up holding key posts in the intelligence service. ${ }^{110}$ As such, the packaging of lustration within the context of broader economic, political, social, and security measures points to a larger government reform mandate. 
Romania suffers from low levels of citizen trust in government and high levels of corruption (see Table 1). Corruption thrives in all spheres in Romania and it is directly tied to the political class. Perceptions of corruption are fuelled by the pervasive belief that the people who contributed to the previous totalitarian regime continue to obtain legal and business advantages, with $80 \%$ of Romanians polled thinking that corruption levels grew or stagnated even after joining EU. ${ }^{111}$ Since public office holders and industry leaders are largely drawn from former communist elites or Securitate informers, there is a belief that the lack of retroactive justice measures has perpetuated economic and political inequalities. The current laws directly address the perceptions of economic inequality and injustice by focusing on the lustration of economic positions of power, including financial institutions. By lustrating positions of both economic and political power across public and quasi-public institutions, the new laws take on the evidence that the former secret service networks remain in top political, economic, and social positions and are using their positions for personal gains.

The role of former Securitate officers in Romanian society today remains a subject of public anxiety. As Vladimir Tismaneanu, the head of the Presidential Commission for the Study of the Communist Dictatorship in Romania noted, 'people were perplexed noticing the thriving careers of proven Securitate collaborators'. ${ }^{112}$ The Securitate have maintained powerful ties to business elites in the new regime: 'Romanian Securitate agents and activists were the first to benefit from an unregulated transition toward capitalism and a multiparty system. ${ }^{113}$ In 2006, the President of the Institute for the Investigation of the Crimes of Communism summed up the nature of regime change in Romania, 'In ' 89 , only Communism was killed, but the former state security and Communist Party chiefs took the economic power. ${ }^{114}$ The continued involvement of former Securitate officers in political and economic networks fuels citizen perceptions that the transition was incomplete.

Finally, public opinion on lustration is mixed, reflecting a general sense of confusion about what will correct the problems in Romanian society. Student organizations have called for the lustration of deans and academics, and unions have lobbied for lustration of their leaders and representatives. ${ }^{115}$ A civic association of journalists has pushed for lustration of the media. ${ }^{116}$ In early $2006,50 \%$ of citizens polled wanted lustration to immediately come into force, and more than half of citizens wanted the archives made publicly accessible on the internet. ${ }^{117}$ However, only $43 \%$ thought lustration might be useful and $47 \%$ thought it might have no impact whatsoever. ${ }^{118}$ A similar poll later in 2006 showed that $36 \%$ of persons polled felt that society would be 'cleaner and more honest' after lustration, with $33 \%$ showing an interest in revelations, and $47 \%$ showing no interest at all. ${ }^{119}$ Given the mixed views on the impact of lustration, it does not appear likely that the party in power designed extensive and controversial lustration laws to tap into populist sentiments in order to gain a short term, direct political advantage.

However, a political manipulation alternative hypothesis remains compelling in the context of Romania. Domestic political fights over lustration and interparty 
accusations of collaboration have impacted all Romania's lustration efforts, and continue to block the implementation of ratified laws. ${ }^{120}$ The 2006 lustration law proposal turned into a hotly contested and morally charged national debate, passing in the Senate by a single vote, and largely opposed by the political parties who were Communist Party holdovers. ${ }^{121}$ Lustration changes were expected to affect at least 100 current MPs in Parliament, which would have substantially changed the parliamentary balance of power. ${ }^{122}$ These events are all consistent with an explanation of lustration as a by-product of competition between political parties.

Nonetheless the evidence does not fit neatly into a party politics explanation. The primary supporters of lustration, the National Liberal Party, were politically disadvantaged by the laws. ${ }^{123}$ They have been the party most affected by collaboration accusations, with top Liberal officials expelled from the party, including their very popular minister of culture, Mona Musca. ${ }^{124}$ Basescu's 'explicit and categorical' condemnation of the previous communist system and its record of atrocities was also a politically precarious position to take in favour of lustration and transparency. ${ }^{125}$ President Basescu's speech was received by a divided and hostile Parliament, and a December 2007 Public Opinion Barometer poll in Romania showed citizens still considered Ceausescu was the best political leader that Romania ever had. ${ }^{126}$ Basescu pushed forward with the legal initiative and avoided an impeachment attempt only after a popular referendum. ${ }^{127}$ This evidence does not fit with a political manipulation hypothesis, especially given the high potential risk for the president and the party initiating the reforms.

In addressing the question 'why lustrate?', the evidence for a political manipulation hypothesis is lacking. As predicted, there is some opposition to the policies by individuals and parties that might be politically disadvantaged. There is also opposition to the law from the Constitutional Court, which has debated both the appropriateness of all retroactive justice measures as well as the constitutionality of these specific lustration laws. However, neither of these supports an argument that the laws are designed and implemented to advantage a certain party at the expense of adversaries. The fact that the laws are politically motivated and contentious does not lead to the conclusion that they are political manipulated.

Finally, there is some evidence that the late lustration programme was partially designed or timed for international consumption. There was substantial signalling on the part of the Romanian president and prime minister about domestic efforts to clean up their oft-cited problems with corruption, especially right before the final accession negotiations in late 2006. ${ }^{128}$ Therefore, it is possible that Romania's public posturing might have tipped the EU's assessment of Romania at a crucial moment in membership considerations. However, like Poland, the expansive scope of the lustration laws could violate freedoms protected by the European Union's Court of Justice, as well as international obligations under the European Charter of Human Rights and the International Labor Organization. Moreover, the EU has explicitly questioned whether lustration conflicts with underlying EU values. $^{129}$ Therefore, while it is possible that part of the lustration effort was 
designed to appease the international community's concerns about domestic corruption problems, given the international community's lack of clear support regarding the implementation of lustration in other countries, this would have been a highly risky strategy.

In sum, the reasons for late lustration in Romania bear a strong resemblance to the Polish case, despite the different political, economic, and social conditions in the countries. The expansive scope of the Romanian laws, the types of positions targeted, the transparency improvements, and the proliferation of oversight agencies and mechanisms to monitor implementation of the laws all point to a government programme designed to effect broad institutional change, as well as symbolic change. As with the Polish case, lustration and anti-corruption efforts have been conflated in the political sphere. There is a link made between continued corruption and lack of transitional justice by the governments in the region. Lustration efforts are framed in this anti-corruption narrative, and conjoined with economic and political reform efforts. This all suggests that the government enacted late lustration in order to address the evidence and perceptions about economic, social, and political problems that have remained unresolved in the transition.

\section{Conclusion: supporting or undermining democratic transitions?}

Three findings arise from this comparison of late lustration programmes in Poland and Romania. First, late lustration looks substantially different from early lustration programmes and has a different more expansive mandate. Late lustration is aimed broadly at positions of public trust, spanning political, cultural, social, and economic positions. The programmes are not focused either exclusively or myopically on top political office holders, but include positions of trust at national, regional, and local levels. The criteria for collaboration were also loosened in both programmes, signalling a significant change in determining what level of previous secret police or even regime involvement would lead to employment exclusion. The two-pronged expansive scope tackles new policy goals, including anti-corruption and political privileging concerns. The policies are designed to complement and in some cases substitute for anti-corruption measures. Moral cleansing is a dominant theme in both programmes, with a focus on correcting lingering inequalities in terms of economic and political opportunities. This resonates with the symbolic change component of lustration's goals. The similarities of the programmes, the transparency safeguards, and the grouping of lustration with other reform efforts suggest a concerted attempt by the governments to change citizen perceptions of the institutional capacity and integrity of public and quasi-public institutions.

This analysis of the structure and intention of late lustration is an important contribution to the lustration literature, because it highlights the evolving definition of lustration and its intended impact. There remains much debate over the goals of lustration. As lustration expands to include non-political positions, or private sector positions, or changes the criteria for determining collaboration, this will impact the very way the term is used in the transitional justice literature. 
Second, critics have charged that lustration laws are egregious examples of revenge politics, and therefore likely to undermine the democratic transition process. In some countries, lustration has looked very much like revenge politics. However, the evidence of late lustration in Poland and Romania neither supports a strong revenge hypothesis nor a limited hypothesis that the laws are timed or designed for direct political party advantaging. The transparency and accountability measures have changed in the late lustration programmes, directly trying to correct problems with secrecy and limited transparency in the past. In Poland in particular, previous opponents to lustration have changed their minds, and begun to endorse a transparent review of the past. Additionally, in both cases the party initiating the reforms was adversely impacted by the lustration programmes, which works against a traditional argument that lustration laws are tools of party politics designed to confer direct political advantage on the initiating party.

This is an important finding, because the assumption that the laws are politically manipulated a priori sullies an assessment of their impact. This study has tried to disentangle politically motivated laws from politically manipulated laws, highlighting how conflating the two results in sweeping and possibly erroneous assumptions about lustration. Lustration has been prone to political manipulation, but that must be proven not assumed up front.

Third, originally it was thought that lustration needed to be done at the start of the transition or it would be ineffectual and maybe even detrimental to democratic reforms. However, this new evidence does not support the original contention. The waves of late lustration across the region, from Macedonia and Slovenia to Latvia and Slovakia, suggest that CEE countries might be turning to lustration as a way to correct some of the problems associated with post-communist transitions. Even countries that instituted transitional justice measures early in the transition continue to grapple with retroactive justice concerns. In 2007, both the Czech Republic and East Germany moved forward with expansive transparency measures to improve an understanding of, access to, and use of secret police files as part of their continuing programmes addressing retroactive justice concerns. ${ }^{130}$ All of this shows that the timeline for transitional justice in the regime is much more fluid than originally thought. Lustration is resonating with a symbolic and institutional sense that something about the democratic transitions is incomplete.

Whether these expansive late lustration policies will actually improve citizen perceptions about the trustworthiness of public institutions and contribute to democratic consolidation is the subject of future inquiry. In both the Romanian and Polish cases the actual implementation of the laws remains contentious. Bad implementation could undermine the goal of good governance. Lustration could be the latest misplaced panacea for problems with the transition. This paper addresses the first order question, 'why late lustration?' It has shown that the structure and context for the late lustration programmes suggest reformoriented policies to support the democratic consolidation process in the region. 
The second order question, 'does lustration actually improve institutional trustworthiness?', remains open.

\section{Notes}

1. Quoted in David, 'Lustration Laws in Action', 394.

2. United Nations, Rule of Law Tools for Post-Conflict States, 4.

3. Regional arguments against lustration have been made by the Polish leader Tadeusz Mazowiecki and later Lech Walesa while he was Poland's president. See Bertschi, 'Lustration and the Transition to Democracy', 435-451; Michnik and Havel, 'Justice or Revenge', 20-7; Siklova, 'The Czech Way of Screening', 57-62.

International criticism has resonated with national level concerns, see International Labour Organization, Report of the Committee Set Up to Examine the Representation Made by the Trade Union Association of Bohemia, Moravia and Silesia (OS-CMS) under Article 24 of the ILO Constitution; Council of Europe, Lustration Must Not Turn into Revenge Against Former Collaborators.

4. Wiktor Osiatynski, 'Poland Makes Witch Hunting Easier', The New York Times, 22 January 2007 (Warsaw edition), op-ed.; 'The Polish Inquisition', The Wall Street Journal, 27 April 2007 (Brussels edition), editorial; and 'The New Purge in Poland', The Boston Globe, 9 April 2007.

5. Czechoslovakia enacted a lustration program in 1990. After the split, Slovakia used the screening law it inherited until it stopped its lustration program in 1993. In 2002 it approved a National Memory Bill to renew lustration policies, but this did not gain real momentum until 2004. See Kritz, 'Czech and Slovak Federal Republic', 312-21; Radio Free Europe/Radio Liberty, 'Slovakia Makes Files from Communist and Nazi eras Public', RFE/RL Newsline, 6, no. 128, part II, 11 July 2002, http://www.rferl.org; Kubosova, 'Slovakia: Pandora's Box Online'.

6. Gaube, 'Slovenia: A Sorry Spy Hunt'; Aris Jansons, 'Latvia: Spy Games'.

7. 'Macedonian Assembly Legal Committee Approves Lustration Bill', BBC Monitoring European, 23 January 2007, Makfax News Agency, Skopje.

8. Boed, 'An Evaluation of the Legality and Efficacy of Lustration', 357-402; 'Czech Interior Ministry To Start Checking Police for Communist Security Ties', $B B C$ Monitoring European, 19 February 2007.

9. According to the US State Department, Poland's 2007 GDP per capita was $\$ 11,037$, while Romania's was $\$ 5662$. Both had annual GDP growth rates of approximately $6 \%$. See US Department of State, 'Background Notes: Poland and Romania', http:// www.state.gov/r/pa/ei/bgn.htm

10. European Commission, 'Bulgaria and Romania - More Work Needed on Corruption'.

11. David, 'Lustration Laws in Action', 388; Natalia Letki, 'Lustration and Democratisation in East-Central Europe', 530; Williams and Szczerbiak, et al., 'Explaining Lustration in Eastern Europe'.

12. László Sólyom, 'The Role of Constitutional Courts', 133-61.

13. Note, Kaminiski and Nalepa differentiate two forms of truth revelation procedures, confession-based procedures and incentive-based procedures, in order to discuss differences in impact and efficacy. See 'Judging Transitional Justice', 383-408; Mark Gibney, 'Prosecuting Human Rights Violations From a Previous Regime', 93-110.

14. For a lively debate amongst regional scholars over the definition and intent of lustration, see Hatschikjan, Past and Present.

15. 'Poland's Witch Hunt', Irish Times, 30 April 2007, 21.

16. European Court of Human Rights, Case of Sidabras and Dziautas v. Lithuania; European Court of Human Rights, Case of Rainys and Gasparavičius v. Lithuania. 
17. Boed, 'Legality of Lustration', 363; and Bertschi, 'Lustration and the Transition to Democracy', 447.

18. Boed, 'Legality of Lustration'.

19. For an overview of where lustration and vetting are situated within the larger transitional justice debate see Auckerman, 'Extraordinary Evil, Ordinary Crime', 39-97; Minow, Between Vengeance and Forgiveness. The arguments for and against lustration on moral, legal, and procedural grounds have been oft debated, therefore I will not reiterate all of the arguments here. For a review of some of the key issues see Lós, 'Lustration and Truth Claims', 117-61; Welsh, 'Dealing with the Communist Past', 413-29; Posner and Vermeule, 'Transitional Justice as Ordinary Justice', $761-825$

20. Maina Kiai, ‘How Human Rights Principles \& Approaches'; United Nations, Rule of Law Tools for Post-Conflict States; Williams, 'Lustration as the Securitization of Democracy', 1-24.

21. Council of Europe, Measures to Dismantle the Heritage of Former Communist Totalitarian Systems.

22. United Nations, Rule of Law Tools for Post-Conflict States.

23. For example, see European Court of Human Rights, Case of Ždanoka v. Latvia, 39.

24. Tupy, 'Rise of Populist Parties in Central Europe', 13.

25. Cioflanca, 'Politics of Oblivion', 85-93.

26. Specifically Conor O'Dwyer shows that despite an explosion of new administrative positions and districts in the case of Poland, the locus of power has changed little. See 'Reforming Regional Governance in East Central Europe', 246-7.

27. David, 'Lustration Laws in Action', 394.

28. Ibid., 414 fn 63.

29. This assertion was supported by similar allegations made by former Prime Minister Karimierz Marcinkiewicz. See Simonov, 'Purging Eastern Europe of Evil'; Michael Szporer, 'Wildstein's List: Time for Moral Cleansing?', SIEC News (2005), http:// www.polishnews.com/text/politics/wildsteins_list.html (accessed 18 May 2007).

30. Grigorescu, 'The Corruption Eruption in East-Central Europe', 517; Paczynska, 'Inequality, Political Participation, and Democratic Deepening in Poland', 603-4.

31. Stan, 'Politics of Memory in Poland; Vladimir Tismaneanu quoted in Claudia Ciobanu, 'Court Suspends Council's Inquiries into Secret Service', Inter Press Service, 11 February 2008 (Bucharest, Romania); Wolek, 'Lustration as a Struggle', 147-201.

32. Huntington, Third Wave, 151-61.

33. The 'thick line' is a reference to the philosophy espoused by Tadeusz Mazowiecku, the first non-communist prime minister of Poland (1989). It captures the policy of drawing a thick line between the past and the future. See Bertschi, 'Lustration and Transition to Democracy'.

34. Wojciech Kosc, 'Poland: Wildstein's List', Transitions Online, Policy Briefs, 1-7 February 2005. http://www.ciaonet.org/pbei-2/tol-1/tol_2005/feb1-feb7/feb1feb7g.html

35. Posner and Vermeule, 'Transitional Justice as Ordinary Justice', 825.

36. Offe, Varieties of Transition; Offe, 'Coming to Terms with Past Injustices', 195-201.

37. Kiss, 'The Misuses of Manipulation; Barrett, Hack, and Munkácsy, 'Lustration as Political Competition', 260-307.

38. Austin and Ellison, 'Post-Communist Transitional Justice in Albania', 374.

39. Kaminski and Nalepa, 'Judging Transitional Justice'.

40. 'Europe's Marxist Dilemma', The Economist, 24 April 2008, 72. Visegrad refers to the original group of four countries seeking European Union integration, namely the Czech Republic, Hungary, Poland, and Slovakia. 
41. Boed, 'Legality and Efficacy of Lustration', 447; Bertschi, 'Lustration and the Transition to Democracy', 444; Ellis, 'Purging the Past', 192.

42. ' No Comeback for Gilowska?', The Warsaw Voice, 9-16 July 2006, 16.

43. Gerald Owen, 'A Revolution Purges Its Own', National Post (Ontario), 12 January 2007; Stan, 'Politics of Memory in Poland', 18.

44. Stan, 'Politics of Memory in Poland', 29-30.

45. For a copy of the list see http://www.humanrightshouse.org/; and 'Screening Poland's Past: We've Got a Little List', The Economist, 12 August 2006, 42.

46. Stan, 'Politics of Memory in Poland', 46.

47. Lech's five-year term as president of Poland expires in December 2010; Jaroslaw served as prime minister from July 2006-November 2007. 'Poland's Purges: False Lustre', The Economist, 19 May 2007, 57.

48. Judy Dempsey, '17 Years of Reform Fall Short for Polish Chiefs', International Herald Tribune (Paris edition), 2 November 2006, 3.

49. Tom Hundley, 'Poland Looks Back in Anger', Chicago Tribune, 28 November 2006, 10.

50. Stan, 'Politics of Memory in Poland', 18.

51. In 2007 there was a very public outing of the soon to be Archbishop of Warsaw over collaboration revelations just as he was being appointed to the new position by Rome. 'Poland and the Past: Tainted Vestments', The Economist, 13 January 2007, 47; Craig Smith, 'New Warsaw Archbishop Quits Over Communist Collaboration', The New York Times, 8 January 2007, http://www.nytimes.com/ 2007/01/08/world/europe/08poland.html

52. 'Lustration Law Amended', PolishNews, Issue 71 (1), on-line news, March 2002, http://www.polishnews.com/fulltext/straight/2002/hotnews71_1.shtml

53. 'New Law in Poland Aims to Oust Officials Who Aided Secret Police', The New York Times, 15 March 2007, http://www.nytimes.com/2007/world/europe/ 16poland.html; and 'Polish Academics Brace for Anti-communist Come-Clean Law', Agence France-Presse, 14 March 2007.

54. Mite, 'Poland: Tough Lustration Law'.

55. Ellis, 'Purging the Past', 193.

56. McLaughlin, 'Thousands May Lose Job in Purge', 9.

57. Polish Constitutional Court, Judgement of 11 May 2007, File Ref. No. K2/07 LUSTRATION (Fundamental arguments). English translation by Marek Lukasik, Judicial Decisions, http://www.trybunal.gov.pl/eng/index.htm

58. 'Professor Bronislaw Geremek, the Member of the European Parliament', AXIS News, 5 March 2008. Available at www.axisglobe.com/pnnt_news.asp?news= 12629, accessed 10 June 2008.

59. Kaminiski and Nalepa, 'Judging Transitional Justice', 384.

60. Anne Penketh, 'Poles Apart', The Independent (London), 28 May 2007, http://docs. newsbank.com/openur/

61. Andy McSmith, 'Why Has Lech Walesa Published the Files Kept on Him by Polish Police?', The Independent (London), 13 June 2007, http://docs.newsbank.com/ openur/

62. Grigorescu, 'The Corruption Eruption in East-Central Europe', 517.

63. 'Poland's Purges: False Lustre'.

64. See Paczynska, 'Inequality, Political Participation, and Democratic Deepening in Poland', for a discussion of rising economic inequality and perceptions of unfairness and dissatisfaction with public institutions in Poland. Mishler and Richard, 'What Are the Origins of Political Trust; Mishler and Rose, 'Trust, Distrust, and Skepticism'.

65. Kosc, 'Poland: Wildstein's List'. 
66. 'Polish Report Views Impact of Secret Service Reforms, "Unprecedented Suspicion", Polityka, in BBC Monitoring European, Warsaw, 4 November 2006.

67. Economist Intelligence Unit, 'Poland Politics: The End of the Line?', EIU Views Wire, 22 September 2006.

68. Simonov, 'Purging Eastern Europe'.

69. 'Screening Poland's Past,' 42.

70. 'Polish Inquisition', 12.

71. Letki, 'Lustration and Democratisation in East-Central Europe'.

72. Los and Zybertowicz, Privatizing the State-Police, quoted in Stan, 'Politics of Memory in Poland', 15.

73. Stan, 'The Politics of Memory in Poland', 10.

74. Kritz, 'The Dilemmas of Transnational Justice', Transitional Justice, xxxv; and David, 'Lustration Laws in Action', 426.

75. 'New Law in Poland Aims to Oust Officials'.

76. Hundley, 'Poland Looks Back', 10.

77. 'Polish Academics Brace', 10.

78. This group of 'young politicians' has been referred to as 'Generation 72', a reference to the 1972 cut-off date for screening. See Derek Scally, 'Poles Split Down the Middle over Digging Up the Past', Irish Times (Dublin), 22 January 2007; Osiatynski, 'Poland Makes Witch Hunting Easier'.

79. Stan, 'The Politics of Memory in Poland', 51.

80. Cienski, 'Poland's Anti-Communist Witch-Hunt', 6.

81. Memorandum to the Polish Government.

82. 'Human Rights Commissioner Presents Memorandum on Poland'.

83. Helsinki Committee, Helsinki Committee of Poland.

84. Stan, 'The Romanian Anticorruption Bill', 18; Lidia Moise, 'Seven Unsolved Problems That Make Brussels Worry', Libera, Bucharest, translated in BBC Monitoring Original Source, 7 January 2008; European Commission, 'Bulgaria and Romania - More Work Needed'.

85. For details about the Proclamation of Timisoara, especially section 8 that deals directly with lustration, see http://www.ceausescu.org/ceausescu_texts/revolution/ procl_tm_eng.htm

86. Gibney, Prosecuting Human Rights Violations', 97.

87. Welsh, 'Dealing with the Communist Past', 416.

88. Neculai Munteanu, 'Daily Views Persisting Influence of Securitate, Communists in Romania', Ziua, Bucharest, translated in BBC Monitoring European, 4 April 2006; 'What the Newspapers Say: March 30, 2006', HotNews.ro, 30 March 2006, http:// english.hotnews.ro/what-the-newspapers-say-March-30-2006-articol/_pnnt 42405 Z, accessed 21 September 2006.

89. Lovatt, 'Securitate Shuffle'.

90. 'Romanians May See Own Securitate Files', Radio Free Europe/Radio Liberty, Southeastern Europe edition, 10 January 2001. Emailed daily news reports, archives available at http://www.rferl.org/info/Newsline+Archive/494.html

91. 'The Lustration Law Was Passed by the Senate', HotNews.ro, 10 April 2006, http:// www.hotnews.ro/articol_46347-Legea-lustratiei-a-trecut-de-Senat.htm; Ciobanu, 'Court Suspends Council's Inquiries'.

92. Konrad-Adenauer-Stiftung, 'Status Quo of "Lustration" in South East Europe'.

93. Mirela Corlatan, 'A Lustration Law for Romania', Euro-topics, 25 May 2007, available at http://www.auacademic.com/meta/p_mla_apa_research_citation; Catalin Bogdan, 'Far From Unanimous Condemnation', Nine o'clock, no. 3835 (20 December 2006): 4, available at http://www.nineoclock.ro/

94. Ciobanu, 'Court Suspends Council's Inquiries'. 
95. Annett Müller, 'Sluggish Processing of the Past', Euro-topics Magazine, 5 February 2008, http://www.eurotopics.net/en/magazin/stasi-2008-01/mueuer_vergangen heitsaufarbeitung, accessed 12 May 2008.

96. Public trust in the courts is low, with high levels of judicial corruption and a lack of transparency. The Court also recently struck down a law requiring public wealth disclosures for dignitaries that was required by the EU as part of a new transparency effort. The objectivity of the Courts has been questioned by both the public and the government on this and related reform efforts. See 'Constitutional Court: Law allowing the control of dignitaries' wealth is not constitutional', HotNews.ro, 16 April 2008; Stan, 'The Romanian Anticorruption Bill'.

97. 'What the Newspapers Say, May 3, 2006', HotNews.ro, http://english.hotnews.ro/ what-the-newspapers-say-May-3-2006-articol-print_4267_2, accessed 21 September 2006.

98. 'The Stain of Exposure', Radio Romania International (17 August 2006), Bucharest, http://www.rri.ro/index.php?lmb=4\&art $=16460$.

99. Alison Mutler, 'Romania Secret Police Files an Obsession', Associated Press News Service (Bucharest), 30 August 2006.

100. 'Deputies Endorse Law for Revealing Securitate Collaborators', HotNews.ro, 21 September 2006 update, 11 April 2006 original. Available at http://english. hotnews.ro/Deputies-endorse-law-for-revealing-Seacuritate-collaboraters-articol, accessed 21 September 2006.

101. The four types of funds are the Criminal Fund, the Operative Fund, the Intelligence Fund, and the Correspondence, Reports, Analyses and Syntheses Fund. The Operative Fund contains information about individuals who were pursued or monitored by the Securitate. The Intelligence Fund includes information on informers and collaborators. The Criminal Fund includes information related to criminal trials. The Correspondence, Reports, Analyses and Syntheses Fund includes historical information about the evolution and structure of the Securitate. 'Romanian Report: Entire Securitate Archive on Microfilm, Computers', $B B C$ Monitoring European (London), 30 April 2006.

102. Adriana Mica, 'The Lustration with Two Heads and the Myriapod Transitional Justice in Romania', paper presented at annual meeting of Law and Society Organization. Berlin 25 July 2007. Paper uploaded 2008, http://www.memoria.ro/ ?location $=$ view_article $\&$ id $=1881 \& 1=$ en $\&$ page $=2$

103. Stan and Turcescu, 'The Devil's Confessors', 655-85.

104. 'A Bad Mark for the Judiciary?'; 'Where Does Romanians' Trust Lie?', Radio Romania International (Bucharest), 13 September 2006, http://www.rri.ro/ index.php?lmb=4\&art=17068; 'The Romanian Media as Perceived by the Population', Radio Romania International (Bucharest), 26 July 2006, http:// www.rri.ro/index.php?lmb=4\&art $=15501$

105. Catalin Bogdan, 'A Past Still Locked', Nine O'Clock, no. 3640 (16 March 2006), 4; Catalin Bogdan, 'Securitate, a Persistent Mystery', Nine O' Clock, no. 3647 (27 March 2006), 4.

106. 'Deputies Endorse Law'.

107. 'Romanian Party Leader Sees Ethnic Hungarian Party as Potential Partner', Magyar Nemzet (Budapest), translated in BBC Monitoring, 24 May 2007; 'Romania's President Consults Political Parties', BBC Monitoring Original Source: Rompres News Agency Bucharest, 28 May 2007.

108. The draft law for the creation of a National Integrity Agency would have directly targeted government corruption. 'A Bad Mark for the Judiciary?', Radio Romania International (Bucharest), 13 September 2006, http://www.rri.ro/index.php? $\operatorname{lmb}=4 \&$ art $=17068$, accessed 21 September 2006. 
109. 'Citizens and National Security Laws', Radio Romania International (Bucharest), 1 September 2006, http://www.rri.ro/index.php?lmb=4\&art=16785, accessed 21 September 2006.

110. Craig Smith, 'Eastern Europe Still Struggles to Purge Its Security Services', The New York Times, International Section, 12 December 2006.

111. For a discussion of the compatibility problem see Stan, 'Romanian Anticorruption Bill', 2; see also 'The Moral Reform of Justice', Radio Romania International (Bucharest), 10 July 2006, http://www.rri.ro/index.php?lmb=4\&art=15578, accessed 21 September 2006; and 'Survey: Traffic Police Seen as Most Corrupt Institution Within Romanian Ministry', Hotnews.ro, 16 November 2007. Archived in http://english.hotnews.ro/

112. Ciobanu, 'Court Suspends Council's Inquiries'.

113. 'The Lustration Law Under Public Debate', Radio Romania International (Bucharest), 12 May 2006, http://www/rri.ro/index.php\&lmb=4\&art=14004.

114. Smith, 'Eastern Europe Still Struggles'.

115. 'Time for Moral Cleansing', Radio Romania International (Bucharest), 7 August 2006, http://www.rri.ro/index.php?lmb=4\&art=16238, accessed 21 September 2006.

116. 'Moral Reform in the Media?', Radio Romania International (Bucharest), 28 August 2006, http://www.rri.ro/index.php? $1 \mathrm{mb}=4 \&$ art $=16690$, accessed 21 September 2006.

117. 'Lustration Under Public Debate'.

118. 'Romanians Rather Indifferent Toward Former Securitate', HotNews.ro, 29 November 2006 update; 8 May 2006 original edition. Available at http://english. hotnews.ro/Romanians-rather-indifferent-towards-former-Securitate-articol_, accessed 21 September 2006.

119. 'Romanians Skeptical About the Former Collaborators' Revelation', HotNews.ro, 29 November 2006 update, 6 September 2006 original edition. Available at http://english.hotnews.ro/Romanians-sceptical-about-the-former-collaboratorsrevelation-articol_print_423442, accessed 21 September 2006.

120. 'Draft Law on Lustration Fails Again', HotNews.ro, 21 September 2006 update, 21 March 2006 original. Available at http://english.hotnews.ro/Draft-law-on-lustrationfails-again-articol_, accessed 4 January 2007.

121. 'A Hot Summer for Romanian Politics', Radio Romania International (Bucharest), 10 July 2006, http://www.rri.ro/index.php? $1 \mathrm{mb}=4 \&$ art $=15579$, accessed 21 September 2006; and 'Romanian President, Opposition, Nationalist Party Criticizes Lustration Bill', BBC Monitoring European (London), 18 April 2006.

122. 'What the Newspapers Say: April 03, 2006', HotNews.ro, original 3 April 2006, updated 21 September 2006.

123. 'Romanian Political Files Under Scrutiny', Radio Romania International (Bucharest), 15 August 2006, http://www.rri.ro/index.php?lmb=4\&art=16393, accessed 21 September 2006.

124. 'The End of a Political Career', Radio Romania International (Bucharest), 4 September 2006, http://www.rri.ro/index.php?lmb=4\&art=16856, accessed 21 September 2006; and 'Top Liberals Expelled from the Party', HotNews.ro, 4 September 2006.

125. 'Basescu: The Communist Regime in Romania Was Illegitimate and Criminal', Nine O'clock, no. 3834 (19 December 2006), 1.

126. 'Ex-Communist dictator Ceausescu Seen as Best and Worst Political Leader in Romania', HotNews.ro, 6 December 2007. Available in archives http:// english.hotnews.ro 
127. 'What the Newspapers Say: March 30, 2006', HotNews.ro, 30 March 2006, available at http://english.hotnes.ro/What-the-newspapers-say-March-3002006articol_print_4205_2, accessed 21 September 2006; 'President Launches Fierce Attack Against PM on TV', HotNews.ro, 21 September 2006 edition, 5 April 2006 original, available at http://english.hotnews.ro/Presisdent-launches-fieceattack-against-PM-on-TV-articol_print, accessed 21 September 2006; and 'Romania's President Discusses Need to Meet Priorities with Parliament Support', Rompres news agency Bucharest, translated in BBC Monitoring Original Source, 21 May 2007.

128. Grigorescu, 'Corruption Eruption', 544-5; and 'Europeans Critical of Romania and Bulgaria', New York Times, World Briefing, 27 June 2007.

129. Michael Jordan, 'Ex-communist Purge Bumps Up Against EU Values', The Christian Science Monitor, 1 May 2007, 4.

130. The Czech Republic approved the creation of a new Institute for Studies of Totalitarian Regimes, which will administer the secret police files and continue to conduct research. 'Czechs To Have an Institute Dedicated to Totalitarian Past', Deutsche Press-Agentur as translated in Global News Bank, 26 June 2007. East Germany approved a grant to fund efforts to piece together the shredded secret police files in order to address continuing retroactive justice concerns. See JeanBaptiste Piggin, 'Computers Restore Ripped Up German Secret Files', Deutsche Press-Agentur translated in Global News Bank, 9 May 2007. Available at http:// infoweb.newsbank.com-iw-search-we?InfoWeb/?, accessed 19 April 2008.

\section{Note on contributor}

Cynthia M. Horne is an Assistant Professor of Political Science at Western Washington University. The author wishes to thank Deborah Elms, Alexandra Vacrox, Regina Smyth, and the participants at the Warsaw East European Annual Conference in the summer of 2007 for their feedback and helpful advice. This manuscript is much stronger as a result of the helpful critiques from the anonymous reviewers at Democratization. This research benefited greatly from two summer research grants provided by Western Washington University.

\section{Bibliography}

Auckerman, Mirian. 'Extraordinary Evil, Ordinary Crime: A Framework for Understanding Transitional Justice'. Harvard Human Rights Journal 15, no. 39 (2002): 39-97.

Austin, Robert, and Jonathan Ellison. 'Post-Communist Transitional Justice in Albania'. East European Politics and Societies 22, no. 2 (2008): 373-401.

Barrett, Elizabeth, Peter Hack, and Ágnes Munkácsy. 'Lustration as Political Competition: Vetting in Hungary'. In Justice as Prevention: Vetting Public Employees in Transitional Societies, eds. Alexander Mayer-Riechkh and Pablo De Greiff, 260-307. New York: ICTJ and Social Science Research Council, 2007.

Bertschi, C. Charles. 'Lustration and the Transition to Democracy: The Cases of Poland and Bulgaria'. East European Quarterly 28, no. 4 (January 1995): 435-51.

Boed, Roman. 'An Evaluation of the Legality and Efficacy of Lustration as a Tool of Transitional Justice'. Columbia Journal of Transitional Law 37, no. 2 (1999): $357-402$.

Cienski, Jan. 'Poland's Anti-Communist Witch-Hunt Risks Business Chaos'. Financial Times, 15 March 2007, 6.

Cioflanca, Adrian. 'Politics of Oblivion in Postcommunist Romania'. Romanian Journal of Political Science 2 (September 2002): 85-93. 
Council of Europe. Lustration Must Not Turn Into Revenge Against Former Collaborators. Strasbourg: Commissioner for Human Rights, 19 March 2007. http://www.coe.int/t/ commissioner/Viewpoints/070319_en.asp

Council of Europe. Measures to Dismantle the Heritage of Former Communist Totalitarian Systems. Resolution 1096 (1996). Parliamentary Assembly, The Council of Europe, Strasbourg, France: 1996. Available at http://assembly.coe.int/Documents/Adopted Text/ta96/ERES1096.HTM

David, Roman. 'Lustration Laws in Action: The Motives and Evaluation of Lustration Policy in the Czech Republic and Poland (1989-2001)'. Law and Social Inquiry 28, no. 2 (2003): 394.

Ellis, Mark. 'Purging the Past: The Current State of Lustration Laws in the Former Communist Bloc'. Law and Contemporary Problems 59, no. 4 (1997): 181-196.

European Commission. 'Bulgaria and Romania - More Work Needed on Corruption', European Commission External Relations and Foreign Affairs, Brussels, 24 July 2008. http:/ec.europa.eu/news/external_relations/080724_1_en.htm

European Court of Human Rights. Case of Sidabras and Dziautas v. Lithuania, Council of Europe. 55480/00 and 59330/00. Strasbourg: ECHR, 2004.

European Court of Human Rights. Case of Rainys and Gasparavičius v. Lithuania, Council of Europe. 70665/01 and 74345/01. Strasbourg: ECHR, 2005.

European Court of Human Rights. Case of Ždanoka v. Latvia. Judgment 58278/00. 16 March 2006. Strasbourg: ECHR, 2006.

Freedom House. Nations in Transit: Democratization from Central Europe to Eurasia 2007. http://www.freedomhouse.hu/index.php?option=com_content\&task=view\&id $=84$

Gaube, Ales. 'Slovenia: A Sorry Spy Hunt'. Transitions Online: Policy Briefs, 23-28 April 2003. http://www.ciaonet.org/pbei-2/tol-1/tol_2003/apr23-28/apr23-28_d.html

Gibney, Mark. 'Prosecuting Human Rights Violations from a Previous Regime: The East European Experience'. East European Quarterly 31, no. 1 (March 1997): 93-110.

Grigorescu, Alexandru. 'The Corruption Eruption in East-Central Europe: The Increased Salience of Corruption and the Role of Intergovernmental Organizations'. East European Politics and Societies 20, no. 3 (2006): 516-49.

Hatschikjan, Magarditsch. ed. Past and Present: Consequences for Democratisation. Proceedings of the Seminar Organised within the project Disclosing Hidden History: Lustration in the Western Balkans, 2-4 July, 2004, Center for Democracy and Reconciliation in Southeast Europe.

Helsinki Committee. Helsinki Committee of Poland, Position: Regarding the Act of Disclosing Information Regarding Security Services Documents. Warsaw, Poland: Helsinki Committee in Poland, Member of International Helsinki Federation for Human Rights in Vienna, 2007.

Human Rights Commissioner Presents Memorandum on Poland Commissioner for Human Rights: Council of Europe. Strasbourg, France, 20 June 2007. http://www.coe.org.pl/ eng/news.htm.

Huntington, Samuel. The Third Wave: Democratization in the Late Twentieth Century. Norman, OK: University of Oklahoma Press, 1991.

International Labour Organization. Czech Republic of the Discrimination (Employment and Occupation) Convention, 1958 (No. 111). Geneva: International Labour Organization, 1994.

International Labour Organization. Report of the Committee Set Up To Examine the Representation Made by the Trade Union Association of Bohemia, Moravia and Silesia (OS-CMS) Under Article 24 of the ILO Constitution Alleging NonObservance by the Czech Republic of the Discrimination (Employment and Occupation) Convention, 1958 (No. 111). Document No. 161995CZE111. Geneva: International Labour Organization, 1994. 
Inter-University Consortium for Political and Social Research. Candidate Countries Eurobarometer Various years. www.iicpsr.umich.edu

Jansons, Aris. 'Latvia: Spy Games'. Transitions Online: Policy Briefs, 18-24 May, 2004. http://www.ciaonet.org/pbei-2/tol-1/tol_2004/may18-24/may18-24_e.html.

Kaminski, Marek, and Monika Nalepa. 'Judging Transitional Justice: A New Criterion for Evaluating Truth Revelation Procedures'. Journal of Conflict Resolution 50, no. 3 (June 2006): 383-408.

Kiai, Maina. 'How Human Rights Principles \& Approaches Can Help in Fighting Corruption'. Commission on Human Rights. United Nations Conference on AntiCorruption Measures, Office of the United Nations High Commissioner for Human Rights. HR/POL/GG/SEM/2006/BP.2. New York: United Nations, 2006.

Kiss, Csilla. 'The Misuses of Manipulation: The Failure of Transitional Justice in Post-Communist Hungary.' Europe-Asia Studies 58, no. 6 (September 2006): 925-40.

Kritz, Neil, ed. 'Czech and Slovak Federal Republic: Screening (Lustration) Law, Act No. 451/1991 (October 4, 1991).' Translated in Transitional Justice. Washington DC: United States Institute of Peace Studies, vol. III (1993): 312-21.

Kubosova, Lucia. 'Slovakia: Pandora's Box Online'. Transitions Online: Policy Briefs, $16-$ 22 November 2004, http://www.ciaonet.org/pbei-2/tol-1/tol_2004/nov16-nov22/ nov16-nov22e.html

Letki, Natalia. 'Lustration and Democratisation in East-Central Europe'. Europe-Asia Studies 54, no. 4 (2002): 529-52.

Lós, Maria. 'Lustration and Truth Claims: Unfinished Revolutions in Central Europe'. Law \& Social Inquiry 20, no. 1 (Winter 1995): 117-61.

Lovatt, Catherine. 'Securitate Shuffle'. Central Europe Review 2, no. 15 (17 April 2000). http://www.ce-review.org/00/15/lovatt15.html.

Konrad-Adenauer-Stiftung. "Status quo of "Lustration" in South East Europe as of 31 January 2008', Rule of Law Program South East Europe. http://www.kas.de/wf/ doc/kas_13092-544-2-30.pdf

Memorandum to the Polish Government: Assessment of the Progress Made in Implementing the 2002 Recommendations of the Council of Europe Commissioner for Human Rights. CommDH (2007), 13, 20 June, Strasbourg: France, 2007.

Mica, Adriana. 'The Lustration with Two Heads and the Myriapod Transitional Justice in Romania'. Paper presented at annual meeting of Law and Society Organization, Berlin, 25 July, 2007. http://www.memoria.ro/?location=view_article\&id=1881\& $1=$ en\&page $=2$

Michnik, Adam, and Václav Havel. 'Justice or Revenge'. Journal of Democracy 4, no. 1 (1993): 20-7.

Minow, Martha. Between Vengeance and Forgiveness: Facing History after Genocide and Mass Violence. Boston, MA: Beacon Press, 1998.

Mishler, William, and Richard Rose. 'Trust, Distrust, and Skepticism About Institutions of Civil Society'. Studies in Public Policy. 252. Glasgow: University of Strathclyde Centre for the Study of Public Policy, 1995.

Mishler, William, and Richard Rose. 'What Are the Origins of Political Trust: Testing Institutional and Cultural Theories in Post-Communist Societies'. Comparative Political Studies 34, no. 1 (February 2001): 30-62.

Mite, Valentinas. 'Poland: Tough Lustratian Law Divides Society', RFE/RL online reports 23 March 2007. Available at http://www.rferl.org/featuresarticle/2007/03/

O'Dwyer, Conor. 'Reforming Regional Governance in East Central Europe: Europeanization or Domestic Politics as Usual?'. East European Politics and Societies 20, no. 2 219-53. 
Offe, Claus. 'Coming to Terms with Past Injustices: An Introduction to Legal Strategies Available in Post-Communist Societies'. Archives Européenes de Sociologie 33, no. 1 (1992): 195-201.

Offe, Claus. Varieties of Transition: The East European and East German Experiences. London: Cambridge University Press, 1996.

Paczynska, Agnieszka. 'Inequality, Political Participation, and Democratic Deepening in Poland'. East European Politics and Societies 19, no. 4 (2005): 573-613.

Posner, Eric, and Adrian Vermeule. 'Transitional Justice as Ordinary Justice'. Harvard Law Review 117, January (2004): 761-825.

Siklova, Jirina. 'The Czech Way of Screening'. East European Constitutional Review Winter (1996): 57-62.

Simonov, Pavel. 'Purging Eastern Europe of Evil - Lustration from KGB Continues'. AxisGlobe Information and Analysis: Russian Section, 15 November 2005. Available at http://www.axisglobe.com/article.asp?article $=480$.

Sólyom, László. 'The Role of Constitutional Courts in the Transition to Democracy: With Special Reference to Hungary'. International Sociology 18, no. 1 (2003): 133-61.

Stan, Lavinia. 'The Politics of Memory in Poland: Lustration, File Access and Court Proceedings', Studies in Post-Communism Occasional Paper, no. 10 (2006).

Stan, Lavinia. 'The Romanian Anticorruption Bill'. Studies in Post-Communism, Centre for Post Communist Studies, St Francis Xavier University, Occasional Paper no. 6 (2004).

Stan, Lavinia, and Lucian Turcescu. 'The Devil's Confessors: Priests, Communists, Spies, and Informers'. East European Politics and Societies 19, no. 4 (2005): 655-85.

Transparency International. Corruption Perceptions Index. Various years http://www. transparency.org/policy_research/surveys indices/cpi/2001

Tupy, Marian. 'The Rise of Populist Parties in Central Europe: Big Government, Corruption, and the Threat to Liberalism'. Development Policy Analysis. Washington, DC, Cato Institute: Center for Global Liberty \& Prosperity, 2006.

United Nations. Rule of Law Tools for Post-Conflict States: Vetting: An Operational Framework. Office of the UN High Commission on Human Rights, New York United Nations. HR/PUB/06/5 2006.

US Department of State. 'Background Notes: Poland and Romania', http://www.state.gov/ $\mathrm{r} / \mathrm{pa} / \mathrm{ei} / \mathrm{bgn} / 35722 . \mathrm{htm}$.

Welsh, Helga. 'Dealing with the Communist Past: Central and East European Experiences after 1990'. Europe-Asia Studies 48, no. 3 (1996): 413-29.

Williams, Kieran. 'Lustration as the Securitization of Democracy in Czechoslovakia and the Czech Republic'. Journal of Communist Studies and Transition Politics 19, no. 4 (December 2003): 1-24.

Williams, Kieran, and Aleks Szczerbiak, et al. 'Explaining Lustration in Eastern Europe: A Post-Communist Politics Approach'. SEI Working Paper. Sussex European Institute, 2003.

Wolek, A. 'Lustration as a Struggle for a New Rules of Politics and a Legitimacy Enhancement in the New Democracies'. Studia Polityczne no. 15 (2004): 147-201. 